\title{
SISTEM AKUNTANSI PENJUALAN DENGAN METODE CASH AND CARRY PADA PT RANUM GOWA
}

\author{
Andi Asirah \\ Fakultas Ekonomi, Universitas Patria Artha Gowa-Makassar, Program Studi Akuntansi \\ Email: syra.sheren@yahoo.com
}

\begin{abstract}
This research aims to determine the sales accounting system by cash \& carry to PT Ranum. The effective sale of a product by the company is a determinant in the company's activities. These conditions motivate companies to apply cash sales accounting systems to get good income. The method used in the implementation of this research is descriptive method. There are 2 types of data used in this research, namely primary data and secondary data. Interview techniques and observation techniques were used for data collection in this research. The results obtained are in accordance with the theory, where most companies have implemented an appropriate and effective sales cycle so that they are able to provide support for internal sales control.
\end{abstract}

Keywords: cash, carry, system, accounting, sales.

\begin{abstract}
Abstrak
Penelitian ini bertujuan untuk mengetahui sistem akuntansi penjualan dengan cara cash and carry terhadap PT Ranum. Penjualan yang efektif suatu produk oleh perusahaan adalah penentu dalam aktivitas perusahaan. Kondisi tersebut memotivasi perusahaan dalam penerapan sistem akuntansi penjualan tunai untuk mendapatkan penghasilan yang baik. Metode yang digunakan dalam pelaksanaan penelitian ini adalah metode deskriptif. Ada 2 jenis data yang digunakan dalam penelitian, yaitu data primer dan data sekunder. Teknik wawancara dan teknik observasi digunakan untuk pengumpulan data pada penelitian ini. Diperoleh hasil penelitian yang sudah sesuai dengan teori, dimana perusahaan sebagian besar sudah menerapkan siklus penjualan yang tepat dan efektif sehingga mampu memberi dukungan terhadap pengendalian intern penjualan.
\end{abstract}

Kata kunci: cash, carry, system, akuntansi, penjualan

\section{Pendahuluan}

Pada umumnya setiap perusahaan baik itu perusahaan berskala besar, menengah, maupun kecil selalu berusaha menciptakan hubungan bisnis yang sehat. Penjualan merupakan salah satu kegiatan yang penting dalam perusahaan karena sumber utama pendapatan perusahaan berasal dari penjualan. Penelitian ini pernah dilakukan oleh Feni Oktavianty, dkk (2017) pada PT Perhutani (persero) KBM Agribisnis
III Pusbahnas dengan menyimpulkan bahwa prosedur-prosedur yang diterapkan telah dilaksanakan dengan baik. Dimana terdapat alur pemasaran madu ke outlet/ stockiest serta penjelasannya mengenai alur tersebut. System akuntansi penjualan cash and carry pada PT Perhutani (persero) KBM Agribisnis III Pusbahnas sudah berjalan sesuai dengan system yang ada. Maya Surya Ningsih, dkk (2017) terhadap sistem penjualan tunai dan sistem penjualan kredit yang telah diterapkan 
oleh PT XYZ (Persero) TBBM Panjang secara komputerisasi. Sistem informasi akuntansi penjualan tunai dan penjualan kredit yang diterapkan perusahaan sebagian besar telah sesuai sehingga dapat mendukung sistem pengendalian intern penjualan.

Salah satu perusahaan yang menerapkan sistem informasi penjualan adalah PT Ranum yang bergerak di bidang perminyakan Kab. Gowa, Indonesia. Kedatangan perusahaan minyak kelas dunia ke Indonesia menyebabkan banyaknya persaingan. Perusahaan mereka menuntut adanya perkembangan pada teknologi sistem informasi akuntansi penjualan yang memadai dikarenakan luasnya pasar yang ditangani. Hal ini bertujuan untuk memudahkan transaksi pembelian yang dilakukan konsumen, yang mana nantinya sangat dibutuhkan oleh pihak manajemen. Rasyid dan Haryati (2019) dengan judul penelitian perancangan system informasi akuntansi penjualan tunai pada PT. Buana Sultra Mandiri, hasil penelitian berupa rekomendasi untuk pembuatan system informasi penjualan yang bermanfaat dalam proses kerja dan pengawasan serta pengambilan keputusan perusahaan. Wirajaya Hartono (2018) dalam penelitiannya dengan judul perancangan system akuntansi penjualan tunai pada toko satria ponsel pekanbaru mengusulkan adanya perubahan system akuntansi penjualan tunai dari manual menjadi terkomputerisasi dengan menggunakan aplikasi Microsoft Access.

\section{Tinjauan Pustaka}

Berikut ini definisi penjualan tunai menurut 2 ahli. Warren, Reeve, dan Fess (2008:270) menyatakan bahwa memasarkan barang dagang secara cash oleh perusahaan biasanya dapat dioperasikan dengan 2 cara, yaitu register kas dan dibukukan dalam akunakun. Sementara Mulyadi (2001:455) pembeli wajib membayar harga barang dimuka kepada perusahaan. Jika perusahaan sudah menerima pembayaran, barang dapat diserahkan kepada pembeli. Sistem transaksi ini kemudian dibukukan oleh perusahaan.

Deskripsi Sistem Akuntansi Penjualan Cash and Carry sesuai dengan pernyataan Mulyadi (201:462) menyatakan bahwa ada 5 fungsi penting dalam Sistem Akuntansi Penjualan Cash and Carry, yaitu:

1) Fungsi penjualan

Fungsi ini mempunyai peran penting untuk menerima order dari customer, mengisi invoice penjualan tunai, dan memberikan invoice ke customer sebagai bukti harga barang yang sudah dibayarkan ke fungsi kas. 


\section{Vol. 2 No. 2 Bulan Oktober 2021 - Maret 2022}

2) Fungsi kas

Fungsi ini mempunyai peran penting untuk menerima kas dari customer.

3) Fungsi gudang

Fungsi ini mempunyai peran penting untuk mempersiapkan barang yang telah dipesan oleh customer yang selanjutnya akan diproses di fungsi pengiriman.

4) Fungsi pengiriman

Fungsi ini mempunyai peran penting untuk mengemas dan menyerahkan barang kepada customer yang telah membayar harga barang.

5) Fungsi akuntansi

Fungsi ini mempunyai peran penting untuk membukukan transaksi penjualan dan penerimaan kas yang telah diberikan oleh pembuat laporan penjualan.

Dari penjelasan diatas, secara sederhana kerangka pikir dapat dijelaskan melalui gambar berikut:

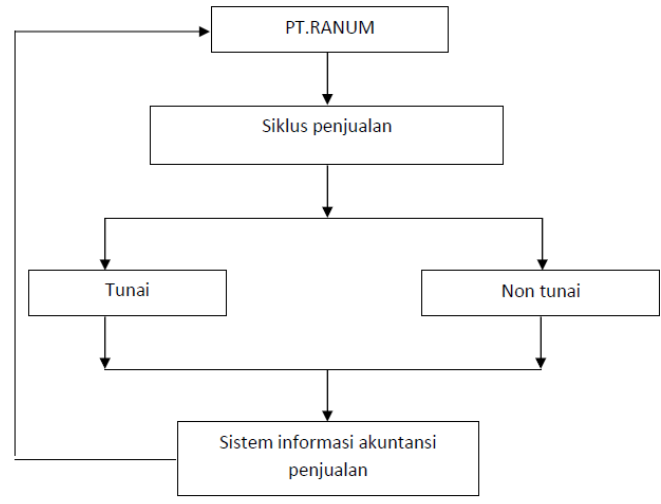

Gambar 1. Kerangka pikir

\section{Metode Penelitian}

Metode yang digunakan dalam pelaksanaan penelitian ini adalah metode deskriptif. Ada 2 jenis data yang digunakan dalam penelitian, yaitu data primer dan data sekunder. Data primer merupakan laporan keuangan tahun 2019 dan tahun 2020 Teknik wawancara dan teknik observasi digunakan untuk pengumpulan data pada penelitian ini

\section{Hasil Penelitian dan Pembahasan}

PT Ranum mengadakan penjualan tunai dan non tunai, yaitu:

a) Penjualan tunai adalah jenis penjualan yang dilaksanakan secara tunai, pembayaran dilakukan oleh pembeli secara cash dan selesai dalam satu kali transaksi

b) Penjualan non tunai yaitu:

- Bayar dimuka yaitu pembayaran harga sebelum barang diterima atau sebelum barang ada

- Bayar dibelakang, yaitu pembayaran yang dilakukan dalam jangka waktu tertentu setelah barang diterima

- COD (cash on delivery), dimana pembayaran dilakukan pada waktu barang diserahkan pada pembeli, dan ada pula yang pembayaran 
dilakukan pada waktu dokumen tiba.

Terdapat 2 jenis penjualan dengan cara cash \& carry di dalam perusahaan, yaitu cash \& carry H2H (Host to Host) dan cash \& carry non $H 2 H$. Hubungan transaksi yang terjadi antara bank dengan perusahaan menggunakan mySAP, dioperasikan dengan sistem H2H. Berikut di bawah ini adalah diagram alur penjualan dengan cara cash \& carry $\mathrm{H} 2 \mathrm{H}$ :

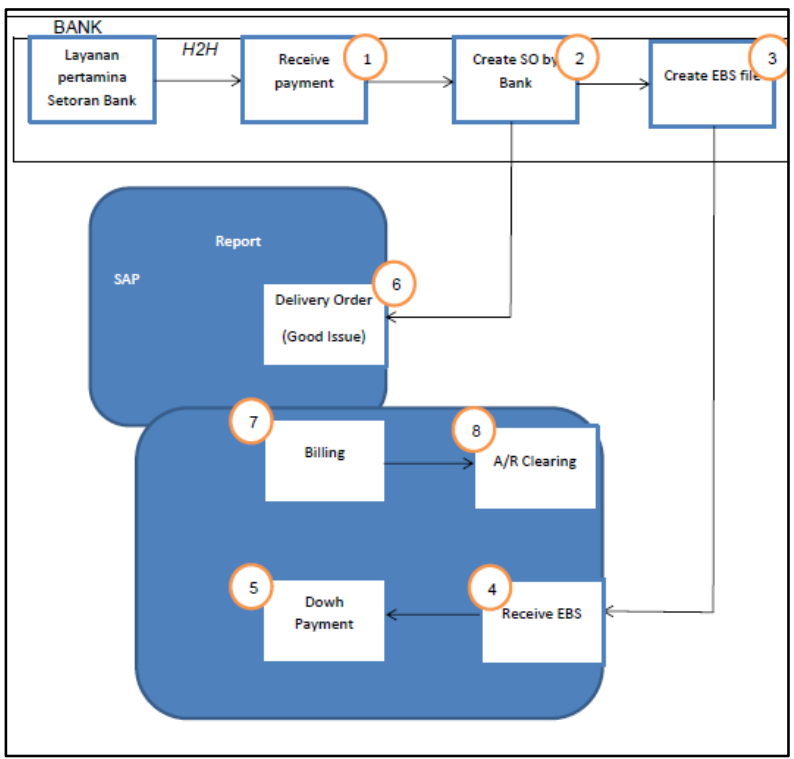

Sumber : Penjualan cash \& carry H2H PT.Ranum

\section{Gambar 2. Proses cash \& carry $\mathrm{H} 2 \mathrm{H}$}

Proses cash \& carry $H 2 H$ mempunyai 8 tahapan, yaitu:

1) Setoran yang diberikan customer kepada bank langsung dapat terhubung ke perusahaan dengan menggunakan sistem $\mathrm{H} 2 \mathrm{H}$.
2) Dilanjutkan dengan pembuatan Sales Order oleh bank yang mencakup 3 aspek, yaitu nama customer, barang yang di-order, dan harga jualnya.

3) Kemudian bank membuatkan Electronic Bank Statement (EBS) untuk customer yang sudah membayar. Cakupan informasi mengenai seluruh data setoran bank pada tanggal tertentu ada di dalam EBS.

4) EBS akan diterima oleh MySAP yang berfungsi untuk mengetahui customer yang telah melakukan transaksi pembayaran ke bank.

5) Data transaksi pembayaran customer yang telah di-update oleh mySAP diproses ke account down payment.

6) Selanjutnya diterapkan proses good issue (jumlah pengiriman berkurang sesuai dengan ketersediaan barang yang ada di dalam gudang).

7) Billing dicetak setelah barang dikirimkan ke customer. Dikarenakan barang belum diambil seluruhnya oleh customer, maka muncul adanya piutang customer. Penyebab barang belum diambil seluruhnya oleh customer dikarenakan tangki di SPBU tidak memadai dan BBM/BBK yang ada di depot juga harus dijaga ketersediannya. 
8) Masuk ke proses pengiriman seluruh barang kepada customer. Dilanjutkan dengan melakukan clearing pada akun piutang yang menghasilkan pendapatan.

Hubungan transaksi yang terjadi antara bank dengan perusahaan tanpa menggunakan sistem $\mathrm{H} 2 \mathrm{H}$ disebut juga penjualan dengan cara cash \& carry non $H 2 H$, menyebabkan transaksi yang terjadi di bank tidak langsung dapat terhubung ke perusahaan yang menggunakan sistem mySAP. Ada 3 faktor yang menyebabkan terjadinya penjualan dengan cara cash \& carry non $H 2 H$, yaitu: bank sedang off system, saldo lebih yang dimanfaatkan oleh customer, dan customer setor kurang bayar. Berikut di bawah ini adalah prosedur penjualan menggunakan cara cash \& carry non $\mathrm{H} 2 \mathrm{H}$ :

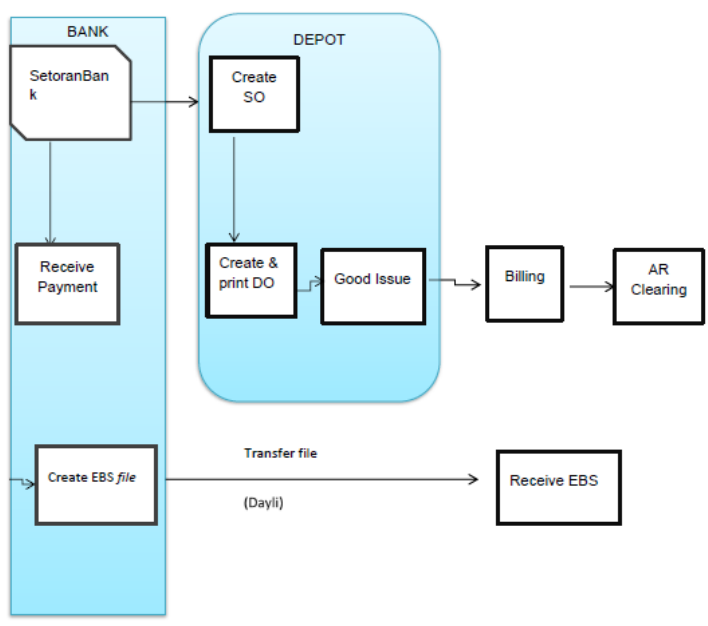

Sumber: Penjualan cash \& carry non H2H: PT Ranum
Berikut ini adalah tahapan prosedur penjualan menggunakan cara cash \& carry non $\mathrm{H} 2 \mathrm{H}$ :

1. Bank memberikan bukti pembayaran kepada customer yang telah melakukan setoran.

2. Pembuatan Electronic Bank Statement file (EBS) oleh bank yang mencakup informasi mengenai seluruh data setoran bank pada tanggal tertentu.

3. Pengiriman Electronic Bank Statement file (EBS) oleh bank ke MySAP yang berfungsi untuk mengetahui customer yang telah melakukan transaksi pembayaran ke bank.

4. Data transaksi pembayaran customer yang telah di-update oleh mySAP diproses ke account down payment.

5. Di depot, dilakukan proses pembuatan Sales Order (SO).

6. Untuk pengambilan barang yang sudah di-order, delivery order dibuat agar dapat menjadi bukti atas pengambilan barang yang akan diserahkan kepada supir.

7. Selanjutnya diterapkan proses good issue (jumlah pengiriman berkurang sesuai dengan ketersediaan barang yang ada di dalam gudang).

8. Kemudian sistem MySAP digunakan untuk membuat billing di depot yang 
Vol. 2 No. 2 Bulan Oktober 2021 - Maret 2022

menyebabkan munculnya piutang customer. Piutang ini muncul karena barang belum dikirim seluruhnya kepada customer.

9. Piutang customer dapat di-clearing setelah barang dikirim seluruhnya.

Salah satu kegiatan dari perusahaan manufaktur yakni penjualan. Perusahaan akan menjual barang dagangannya kepada vendor (pihak pembeli) sesuai dengan syarat yang berlaku dalam perjanjian jual. Jika perusahaan mendapatkan orderan barang dan melakukan penjualan sesuai dengan jumlah barang yang di-order oleh vendor, maka ini disebut transaksi penjualan dengan metode perpetual.

Berdasarkan setahun terakhir pun PT. Ranum mengalami penjualan yang fluktuatif seperti pada semester pertama mulai dari bulan desember 2019 sampai bulan januari 2020 penjualan selalu 300 ribu liter keatas namun pada bulan februari 2020 sampai dengan bulan September 2020, berdasarkan analisa dan hasil penelitian penyebab menurunnya penjualan di PT. Ranum dikarenakan Negara Indonesia terkena dampak dari Corona Virus Diseases 2019 atau COVID-19 yang menyebabkan seluruh sector ekonomi diseluruh Indonesia juga terkena dampak dari musibah tersebut begitupun dengan PT. Ranum Ditandai dengan Penjualan yang menurun dan fluktuatif dari bulan kebulan

Periode penjualan PT. Ranum dalam setahun terakhir terjadi pada bulan april sebesar 17.713 liter Hal ini terjadi karena Pada bulan april pemerintah memberlakukan PSBB dan aturan ketat karena bom besar dari COVID-19 Serta periode terbaik penjualan PT.Ranum Terjadi pada bulan oktober dengan mencapai penjualan sebesar 411.320 liter dan satu-satunya penjualan menembus 400 ribu liter dalam periode setahun Hal ini terjadi karena pada saat 2019 Perekonomian di Indonesia masih kondusif dan belum tersentuh pengaruh dari covid-19.

Dalam penjualan setahun terakhir PT. Ranum salah satunya perusahaan yang masih mampu bertahan ketika perekonomian Indonesia terjadi resesi ekonomi disaat yang lainnya telah gulung tikar dan PT. Ranum masih bisa mendapatkan profit ditengah kepungan musibah yang terjadi di Indonesia, dengan diterapkan sistem informasi yang dilakukan PT. Ranum sangat membantu PT.Ranum mengatur keuangan serta mengelola perusahaan agar terus positif serta dengan adanya sistem informasi ini PT. Ranum dapat menganalisa periode terburuk dan terbaik penjualannya dan dapat mengantisipasi hal-hal terburuk yang terjadi 
seperti sekarang ini musibah dunia covid-19 yang mempengaruhi seluruh sektor ekonomi.

\section{Kesimpulan dan Saran}

\subsection{Kesimpulan:}

Berdasarkan penelitian yang telah dilakukan di PT Ranum Gowa, maka dapat disimpulkan:

1) Ada 2 jenis penjualan dengan cara cash \& carry di dalam perusahaan, yaitu cash \& carry H2H (Host to Host) dan cash \& carry non $\mathrm{H} 2 \mathrm{H}$ pada PT Ranum Gowa dan telah diterapkan dengan baik sesuai dengan prosedur.

2) Dokumen dan laporan hasil penjualan yang dimiliki oleh PT Ranum Gowa cukup baik dan sistematis sehingga dapat mempermudah pengoreksian yang dilakukan.

3) Pada era globalisasi saat ini, penerapan metode yang digunakan dalam Sistem Akuntansi Penjualan sudah berjalan dengan baik. Adapun 2 bagian yang sudah berjalan lancar dalam Sistem Akuntansi Penjualan Cash and Carry pada PT Ranum Gowa mencakup bagian produksi dan pemasaran yang mampu menjalankan tugasnya masingmasing.

\subsection{Saran:}

Untuk peneliti selanjutnya dapat menguatkan penelitian dengan mengaitkan penelitian ini dengan kecanggihan teknologi dan relevansi diterapkannya sistem ini pada saat kondisi sekarang.

\section{DAFTAR PUSTAKA}

Hartono, Wira jaya. 2018. Perancangan system Akuntansi Penjualan Tunai pada Toko Satria Ponsel Pekanbaru. Jurnal Ilmu Komputer dan Bisnis Vol.9 No.1.

Isnawan.Heri 2015, Analisis Sistem Informasi Akuntansi Penjualan Pada CV. Adam Jaya Motor Tuban, Jurnal Universitas Of Muhammadiyah Malang, Malang.

Kurniawan. 2016. Pengaruh Sistem Informasi Akuntansi Penjualan Terhadap Efektivitas Pengendalian Internal Penjualan pada PT. Niaga Swadaya Makassar.Skripsi. Fakultas Ekonomi dan Bisnis Universitas Islam Negeri Alauddin Makassar.

Ningsih, Maya Surya Dkk. 2017. Sistem Informasi Akuntansi Penjualan pada PT XYZ.

M.Sandy Pradhana Putra.2011.Analisis Penerapan Informasi dan Komunikasi Dalam Siklus Penjualan dan Dampaknya Terhadap Efektivitas Pembuatan Laporan Keuangan (studi kasus PT.ranum).Skripsi. Fakultas Ekonomi dan Bisnis Universitas Islam Negeri Syarif Hidayatullah Jakarta. 
Mulyanto.Agus. 2009, Sistem Informasi Konsep Dan Aplikasi,Pustaka Pelajar, Yogyakarta.

Mulyadi. 2016. Sistem informasi Akuntansi,Jakarta:Salemba Empat.

Oktafianty, feni. 2016. Sistem akuntansi penjualan dengan metode cash and carry pada PT Perhutani (persero). Buletin Ekonomi FEUKI Vol.20 No.1.

Rasyid dan Haryati. 2019. Perancangan system informasi akuntansi penjualan tunai pada PT buana sultra mandiri. Jurnal ilmiah ilmu computer Vol.5 no.1.

Romney, M. B \& Steinbart, P. J. 2014. Sistem Informasi Akuntansi. Jakarta: Salemba Empat

Sujarweni,V. W. 2015.Sistem Akuntansi. Yogyakarta: Pustaka Baru Press.

Tavri, Mahyusir D. 2010.Analisa Perancangan Sistem Pengolahan Data. Jakarta: PT. Elex Media Komputindo 